\title{
Comparing Project Complexity across Different Industry Sectors
}

\author{
Marian Bosch-Rekveldt $\mathbb{D}$, Hans Bakker, and Marcel Hertogh \\ Faculty of Civil Engineering and Geosciences, Delft University of Technology, Stevinweg 1, 2628 CN Delft, Netherlands \\ Correspondence should be addressed to Marian Bosch-Rekveldt; m.g.c.bosch-rekveldt@tudelft.nl
}

Received 26 October 2017; Accepted 9 May 2018; Published 24 June 2018

Academic Editor: Emma Diaz Ruiz de Navamuel

Copyright ( 92018 Marian Bosch-Rekveldt et al. This is an open access article distributed under the Creative Commons Attribution License, which permits unrestricted use, distribution, and reproduction in any medium, provided the original work is properly cited.

\begin{abstract}
Increasing complexity of projects is mentioned as one of the reasons for project failure-still. This paper presents a comparative research to investigate how project complexity was perceived by project practitioners in different industry sectors. Five sectors were included: process industry, construction industry, ICT, high-tech product development, and food processing industry. In total, more than 140 projects were included in the research, hence providing a broad view on Dutch project practice. From the complexity assessments, it is concluded that only one complexity element was present in the top complexity elements of projects across the five sectors: the high project schedule drive. The variety of external stakeholders' perspectives, a lack of resources and skills availability, and interference with existing site were found in the top lists of three sectors. It was concluded that a framework to grasp project complexity could support the management of complex projects by creating awareness for the (expected) complexities. Further research could be focused on the subjective character of complexity as well as on the application of cross-sector learning, since this research does show similarities between large technical projects in different sectors.
\end{abstract}

\section{Introduction}

There has been a lot of attention for assessing project complexity in literature in the previous years [1-4]. Several studies show the potential for, and opportunities of, project complexity $[5,6]$ in an attempt to exploit certain complexities and/or explicitly choose to increase complexity, but more often the potential negative consequences of project complexity are emphasized [7]. Since complexity is potentially hindering project performance, better managing project complexity is considered an important research topic, still.

In the tradition of project management, where the dominant paradigm is shifting from a one-size-fits-all approach in the 1950s towards a more contingent approach, more and more it is realized that projects are unique and should be treated as such, explicitly taking into account contextual influences [8-10]. The project management approach should be chosen to best accommodate specific project circumstances and context.

Despite such a supposed "fit-for-purpose" approach, it is felt that there could be similarities in projects in different sectors and these very different projects possibly could learn from each other. This raised the question how project complexities in one sector would compare to project complexities in other sectors. Are similar problems being faced? Whereas literature did report on theoretical insights and debates in the field of complexity $[11,12]$, insight in real project practice was lacking. Therefore, comparative research was performed to investigate how project complexity was perceived by project practitioners in different industry sectors. Also, it was investigated how a framework to grasp project complexity could support the management of complex projects. The following research questions were formulated:

(1) How do practitioners in different industry sectors perceive project complexity in large technical projects?

(2) How could a framework to grasp project complexity be used to improve project performance?

For this study, the earlier published TOE framework to grasp project complexity, with TOE referring to technical, organizational, and external, was selected [1]. This framework, based on extensive literature study as well as empirical data, provided a broad base and enabled a rich view on the potential aspects causing complexity in very different projects. 
Empirical research was performed in different sectors: process industry, construction industry, ICT industry, high-tech product development industry, and food processing industry. These sectors have in common that engineering tasks constitute a main part of all projects, albeit different types of engineering, like software engineering, industrial engineering, mechanical engineering, and civil engineering. These sectors also have in common that project performance is disappointing $[13,14]$. Given the relation between project complexity and project performance [7], exploring similarities and differences in the complexities faced in projects in these sectors might provide opportunities for cross-sectoral learning.

Using both case studies and broader surveys, data was gathered from several respondents in these five industries. In the different researches, slightly different approaches were used because of the different specific scopes, but the common factor in all researches was the use of the TOE framework. More details on the data gathering are provided in the next section.

The relevance of the research is considered from a scientific point of view and a social point of view. To start with the latter: the research is aimed at contributing to the improvement of business practice by a better understanding of project complexity in different industries, thereby improving project performance. Given the high failure rate of projects, social benefits seem evident. From the scientific point of view, this research embraces some of the project management "schools of thought" as distinguished in literature [15]: particularly the factor school and the contingency school, hence illustrating a pluralistic approach in project management research. Also, it contributes to improving the understanding of the notion of complexity in projects.

This paper is structured as follows. In Section 2, the applied methods are discussed, starting with presenting the further developed TOE framework to grasp project complexity which is used as the main source supporting the data gathering. Next, the set-up of the data gathering in the five industry sectors is described. Section 3 presents the results of the five studies with regard to the complexity assessments. This includes a cross-sector comparison of the results, highlighting similarities and differences between the different sectors. In Section 4, the potential value of the TOE framework for practice is discussed. This leads to the implications for managing complex projects and learning across projects as discussed in Section 5. This paper is concluded with the conclusions and recommendations in Section 6 .

\section{Methods}

This paper has the character of a meta-study; the results of five separate researches, which have in common the application of the TOE framework to grasp project complexity, are compared thoroughly. Bringing together these results is expected to contribute to the understanding of practitioners' perspectives on elements causing complexity in their projects.
2.1. Further Developments of the TOE Framework. The framework as published earlier [1] was slightly modified as a result of subsequent research [7]. To modify the framework, a mixed-methods approach was used, combining qualitative and quantitative methods $[16,17]$. As a result, some elements of the framework were adapted or reformulated, some switched category, and the majority of the elements were simply confirmed. In the version of the framework as presented in Figure 1, the T-elements represent the potential complexity causes in the project related to the project scope or content of the project. The O-elements represent the potential complexity causes in the project related to the project internal organization. The E-elements represent all the potential external complexity causes in the project, related to external issues or external organizational complexities.

The intended use of the TOE framework consists of providing the project team a means to create a complexity footprint of the project at hand. By sharing the (expectedly) different views in the project team and with other stakeholders involved, discussion is facilitated and awareness is created for the expected complexities in the project. It is recognized that this should not be a one-off exercise as the project complexities are expected to evolve during the different phases of the project.

2.2. Data Gathering and Methods per Substudy. This section describes the data gathering in the different industry sectors including an elaboration on the specific methods used per substudy. Table 1 shows when the data was gathered and summarizes the number of respondents in each of the studies. Given the fact that in four studies, the data was gathered in $2011 / 2012$, one could argue that the value of this study is limited. The data for the fifth sector was gathered more recently. How time could have influenced the overall picture will be discussed after providing the results.

Large differences are observed in Table 1 regarding the number of projects/respondents involved in the different studies. The nature of the research-evaluating complexity in different industries using an existing framework-dominantly asks for a quantitative approach [18]. We are interested in general information on relative large numbers of projects, as opposed to detailed in-depth information on small numbers of projects, and therefore, a survey is a suitable research tool $[19,20]$. Indeed a web-based survey was applied in studies A and B. However, in the researches carried out in IT, high-tech industry, and food processing industry, only part of the research was related to measuring project complexity, and those researches were organized around indepth case studies, hence explaining the relative limited amount of data from sectors C, D, and E. Details per research, in terms of methods used and data gathered, are provided below.

2.2.1. Sector A: Process Industry. The study described in this section draws heavily upon Chapter 9 of a dissertation [7]. In the survey, respondents were asked to indicate their company's role (owner/contractor/other) and their experience level (as a project manager and working for their company). Next, the respondents had to score each of the 47 elements of 

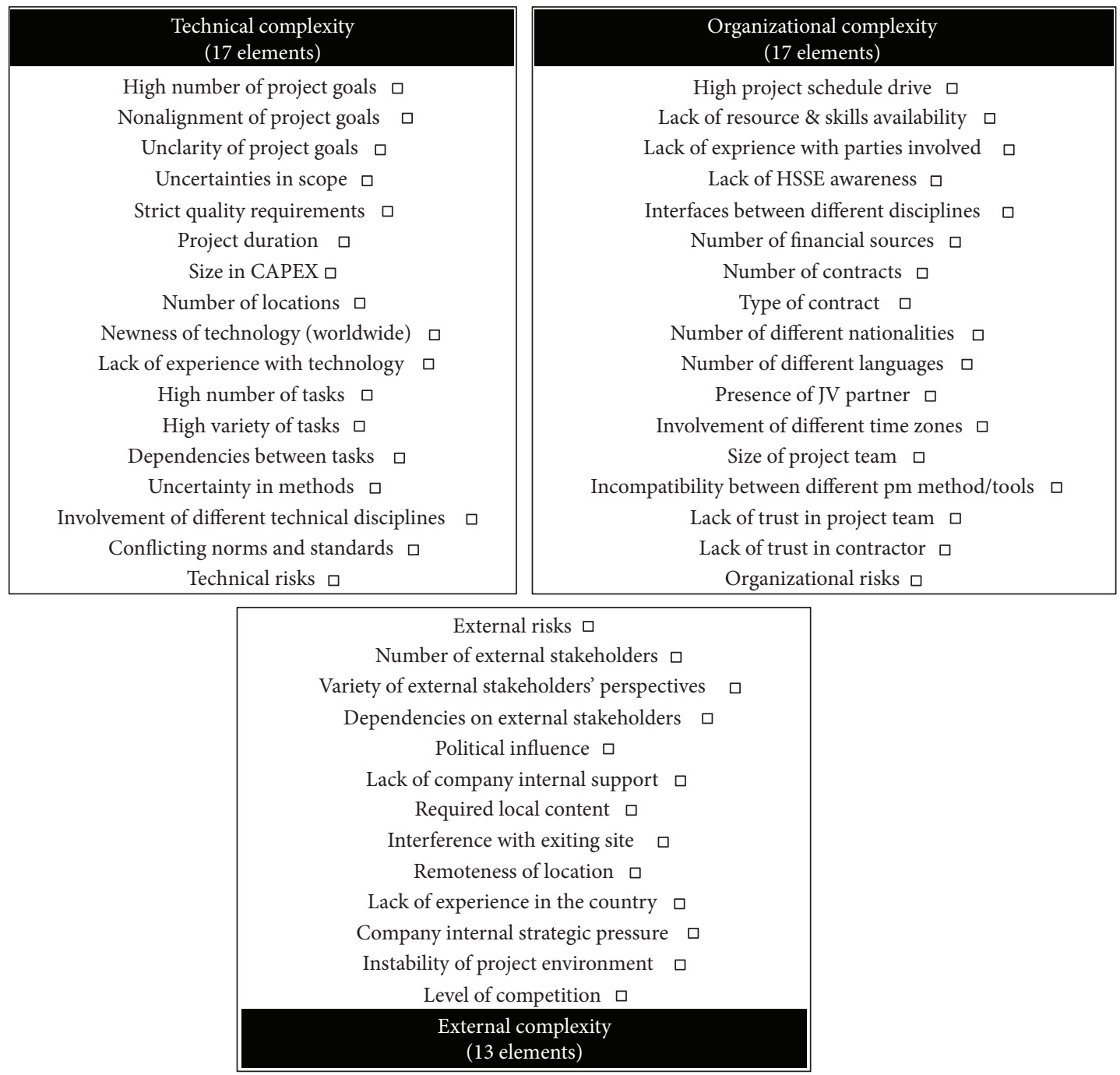

Figure 1: TOE model as used in this study [7].

TABLE 1: Summary of data gathered.

\begin{tabular}{lcccc}
\hline Study ID & Industry & Data gathered in & Number of projects & Number of respondents \\
\hline A & Process & 2011 & 64 & 64 \\
B & Construction and infra & 2012 & 35 & 164 \\
C & IT & 2011 & 8 & 8 \\
D & High-tech product development & 2011 & 16 & 16 \\
E & Food & 2015 & 21 & 25 \\
\hline
\end{tabular}

the TOE framework on their potential contribution to the complexity of a project (not-little-some-substantial-very much). They were not explicitly asked for one specific project; they could answer the question for any project in mind.

Subsequently, the elements that were scored "substantial" or "very much" by the respondent were listed on the screen and the respondent had to select those three elements that in their opinion contribute most to a project's complexity. Next, the elements that were scored "none" or "little" by the respondent were listed on the screen, and the respondent had to select which three of these would contribute least to project complexity. Also, questions were posted regarding treating project complexity, but these are outside the scope of the current paper. Finally, the respondents were asked for their opinion about the potential use of the TOE complexity framework by means of open questions:

(1) How would you apply the TOE project complexity framework in your daily practice?

(2) What would be the added value of using the TOE framework in your projects, if any? 
For the latter part of the survey, open questions were used as they do not restrict the respondent in their answers. The mixture of open questions and closed questions in one survey perfectly fits a mixed-methods approach [21].

In the development and design of the survey, several measures were taken to ensure the internal validity. Before the survey was published on the internet, several experts were asked to test concept versions of the survey. Based on their feedback, questions were reformulated and terminology was clarified. The external validity of this study was positively influenced by the fact that the survey was distributed amongst four totally different companies, all actively involved in the NAP network, the competence network of the Dutch process industry.

Four companies, key players of the NAP network, were selected for participation: two owner companies and two contractor companies. All four approached companies were willing to participate, and the department heads distributed the link to the web-based survey amongst their project managers. In total, 111 survey requests were sent and the survey was started by 68 respondents. Of these respondents, 64 indeed completed and submitted the completed results, hence obtaining a high overall response rate of $58 \%$. For the contractor group (smaller in size), the response rate was a little higher than for the owner group. An overview of the response rate, overall as well as per group (owner/contractor), is given in Table 2 .

While completing the survey, the progress was saved on the participant's computer. Measures were taken to prevent double submissions from one participant. Apart from their typical company role and their work experience, no specific information about the respondents was included in the data analysis. The survey was developed and executed in the web-based application NetQ. The majority of the respondents needed 30 minutes to complete the survey. Data was stored in SPSS compatible format. All data was gathered between February 25th 2011 and March 21st 2011.

2.2.2. Sector B: Construction and Infra. The study described in this section was performed in collaboration with KING (a network consisting of project management teams of large-scale infrastructural projects) and the RijksProjectAcademie (an academy for project managers of public construction projects).

The survey contained similar questions as the survey described in Section 2.2.1, without the part on application of the TOE framework and dealing with project complexities. Both the survey and the TOE framework had to be translated to Dutch because of the dominant use of this language in the Dutch construction sector. Again, an internet survey was used.

After consultation with several experts in the field of construction projects, some elements were added to the TOE framework of Figure 1 while translating it to Dutch in order to increase its applicability to construction industry (see Table 3). As will be shown in Section 3, only 2 of them actually proved relevant for describing project complexity.

In total, 454 project practitioners from 35 projects were invited to participate in the research. For all projects, one
TABLE 2: Overview of responses in study A.

\begin{tabular}{lccc}
\hline Group & Number of requests & Respondents & Response rate \\
\hline Total & 111 & 64 & $58 \%$ \\
Contractor & 35 & 24 & $69 \%$ \\
Owner & 76 & 40 & $53 \%$ \\
\hline
\end{tabular}

or more responses were obtained providing 164 completed surveys in total (response rate of $36 \%$ overall).

Again, the web-based application NetQ was used (program name in the meantime changed to Collector). Data was stored in SPSS compatible format. All data was gathered between July 1st 2012 and September 21st 2012.

2.2.3. Sector C: ICT. A MSc study was undertaken in 2011 to investigate which (combination of) factors determine the complexity of IT projects and how to manage these complexities [22]. Case studies were done in which eight IT projects in the financial services were analyzed. Cases were selected to represent a broad portfolio of projects in the IT sector (infrastructure, application, middleware, and other) and with different performance scores. The case analysis was based on semistructured interviews, held with the project managers of the IT service provider, and detailed project documentation. In the interviews, project managers were asked about their projects: their challenges in projects, their view on the complexity of projects, and how project complexity was actually managed. To identify their view on what factors contributed to the complexity of their projects, the TOE framework as provided in Figure 1 was used.

In the interviews, respondents were asked to indicate to what extent the different elements of the TOE framework contributed to the complexity of the project (not (1)-littlesome-substantial-very much (5)). Data was stored in written interview transcripts and Excel files for storage of the TOE scores. Data was gathered in the Summer of 2011.

2.2.4. Sector D: High-Tech Product Development. Another MSc study was undertaken in 2011 to investigate the benefits of applying the TOE framework in a company developing high-tech products $[23,24]$. Case studies were performed in which 16 high-tech projects were investigated. The amount of 16 cases was considered to provide a good balance between obtaining a broad overview of the projects and in-depth data gathering. Cases were selected from different business lines of the company involved. Selection criteria also included the project nature (product development or process development oriented) and the product design characteristics (new/ old technology). Project managers of the 16 projects were interviewed, with the assumption that the project manager has the most extensive knowledge about the project.

In the interviews, project managers were asked general questions about the project, about the project's complexity, and about its management. Respondents were asked to identify and scale complexities from the TOE framework in relation to their projects (not applicable-very much applicable). Data was gathered in the Summer of 2011. 
Table 3: Comparison TOE elements.

\begin{tabular}{|c|c|c|}
\hline & A: Process industry & B: Construction \\
\hline \multirow{17}{*}{$\mathrm{T}$} & High number of project goals & Aantal projectdoelstellingen \\
\hline & Nonalignment of project goals & Incongruentie van projectdoelstellingen \\
\hline & Unclarity of project goals & Onduidelijkheid over projectdoelstellingen \\
\hline & Uncertainties in scope & Onzekerheid over de scope \\
\hline & Strict quality requirements & Niveau van kwaliteitseisen \\
\hline & Project duration & Projectduur \\
\hline & Size in CAPEX & Investeringskosten \\
\hline & Number of locations & Aantal locaties \\
\hline & Newness of technology (worldwide) & Gebruik nieuwe technologie \\
\hline & Lack of experience with technology & Ervaring met toegepaste technieken \\
\hline & High number of tasks & Aantal deelprojecten \\
\hline & High variety of tasks & Diversiteit van deelprojecten \\
\hline & Dependencies between tasks & Afhankelijkheid tussen deelprojecten \\
\hline & Uncertainty in methods & Onzekerheid over technische methoden \\
\hline & Involvement of different technical disciplines & Diversiteit van technische disciplines \\
\hline & Conflicting norms and standards & - \\
\hline & Technical risks & Technische risico's \\
\hline \multirow{23}{*}{$\mathrm{O}$} & High project schedule drive & Druk op de tijdsplanning \\
\hline & Lack of resource and skills availability & Beschikbaarheid van capaciteit en vaardigheden \\
\hline & & Beschikbaarheid van middelen \\
\hline & & Discontinuïteit in bemensing \\
\hline & Lack of experience with parties involved & Ervaring met projectpartijen \\
\hline & Lack of HSSE awareness & VGM-bewustzijn \\
\hline & Interfaces between different disciplines & Interfaces tussen verschillende disciplines \\
\hline & Number of financial sources & Aantal financieringsbronnen \\
\hline & Number of contracts & Aantal uitvoeringscontracten en interfaces daartussen \\
\hline & Type of contract & Contractvorm \\
\hline & & Kwaliteit van het hoofdcontract \\
\hline & Number of different nationalities & Aantal verschillende nationaliteiten \\
\hline & Number of different languages & Aantal verschillende talen \\
\hline & Presence of JV partner & Samenwerking tussen aannemers \\
\hline & & Aantal opdrachtgevers \\
\hline & Involvement of different time zones & Werktijden \\
\hline & & Bereikbaarheid en bouwlogistiek \\
\hline & Size of project team & Aantal projectmedewerkers \\
\hline & Incompatibility different PM methods/tools & Aansluiting tussen gebruikte PM tools \& technieken \\
\hline & Lack of trust in project team & Vertrouwen tussen projectteam en opdrachtgever \\
\hline & Lack of trust in contractor & Vertrouwen tussen projectteam en aannemer(s) \\
\hline & & Cultuurverschillen \\
\hline & Organizational risks & Organisatorische risico's \\
\hline \multirow{8}{*}{$\mathrm{E}$} & External risks & Externe risico's \\
\hline & Number of external stakeholders & Aantal externe stakeholders \\
\hline & Variety of external stakeholders' perspectives & Diversiteit in belangen van externe stakeholders \\
\hline & Dependencies on external stakeholders & Afhankelijkheid van externe stakeholders \\
\hline & Political influence & Politieke invloed \\
\hline & Lack of company internal support & Management support vanuit de eigen organisatie \\
\hline & Required local content & - \\
\hline & Interference with existing site & Interfaces met andere projecten \\
\hline
\end{tabular}


TABLE 3: Continued.

\begin{tabular}{cc}
\hline A: Process industry & B: Construction \\
Remoteness of location & Aard van de omgeving \\
Lack of experience in the country & - \\
Company internal strategic pressure & Instability of project environment \\
Level of competition & $\begin{array}{c}\text { Invloed van stakeholders van binnen de organisatie } \\
\text { Discontinuïteit bemensing stakeholders } \\
\text { Economische omstandigheden } \\
\text { Marktomstandigheden } \\
\text { BLV bewustzijn }\end{array}$ \\
& Ervaring van omgevingspartijen met grote projecten \\
& Media invloed \\
Sociale impact
\end{tabular}

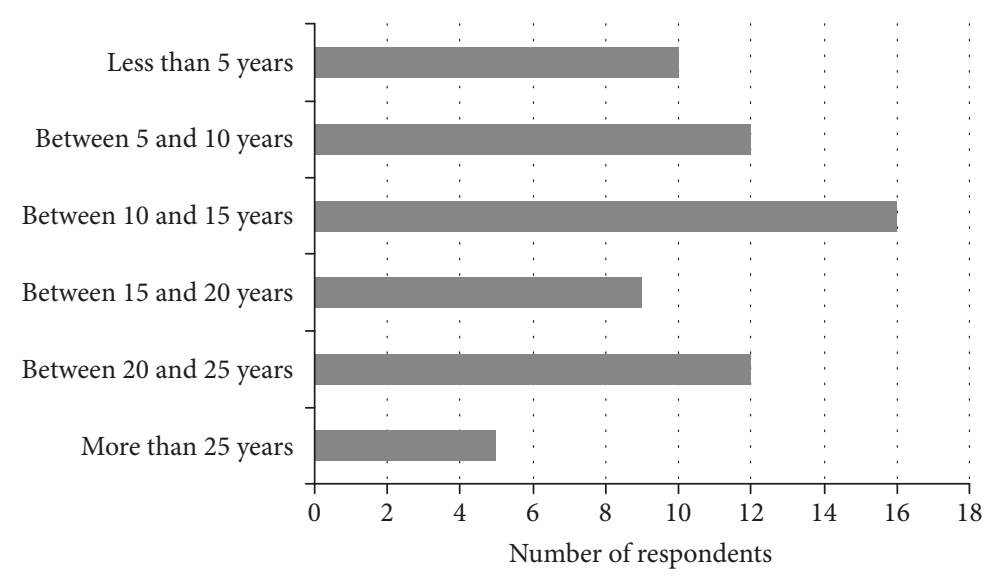

FIgURE 2: Project management experience of respondents $(N=64)$.

2.2.5. Sector E: Food Processing Industry. In the course of 2015 , a study was performed in the food processing industry in one specific company. In total, 21 projects were selected to represent all four business sectors for the project management community in company E. In total, 25 project managers participated in the research.

Semistructured interviews were held including questions about the application of project management processes and the importance of project success criteria. As part of the interview session, the interviewees completed a written TOE complexity assessment for their project (scoring the elements on a 1 (not contributing) to a 5 (most contributing).

Data was stored on answering sheets. Complexity scores were analyzed using Excel.

\section{Results: Complexity Assessments}

Although the various researches provide a rich set of empirical data, this paper will dominantly focus on the results related to the complexity assessments. For each sector, the following findings are discussed: background of the respondents, highest scoring complexity elements in T-, O-, and E-categories, and overall impression of complexity scores.
3.1. Sector A: Process Industry. Respondents were asked for their project management experience. As can be seen in Figure 2, the vast majority of the survey respondents did have considerable project management experience (only 10 out of 64 had less than 5 years of project management experience), thereby increasing the value of this study.

The respondents indicated to what extent the elements of the TOE framework (potentially) contributed to the project's complexity (table with results added in Figure 3). Amongst the highest-scoring elements were the elements related to project goals and scope (unclarity of goals, nonalignment of goals, and uncertainties in scope), boundary conditions for the project (lack of resource and skills scarcity), and softer factors (a lack of trust in the project team, a lack of trust in the contractor). The vast majority of the elements were scored between "some" and "substantial," indicating the perceived relevance of these elements in their contribution to project complexity. Subsequently, respondents indicated their top3 s of most contributing elements (see Table 4).

Comparing the results in Figure 3 and Table 4, all highest-scoring elements of Figure 3 appear in the top-3, except for the element lack of trust in the contractor. Table 4 shows that the top- 3 of most often mentioned 


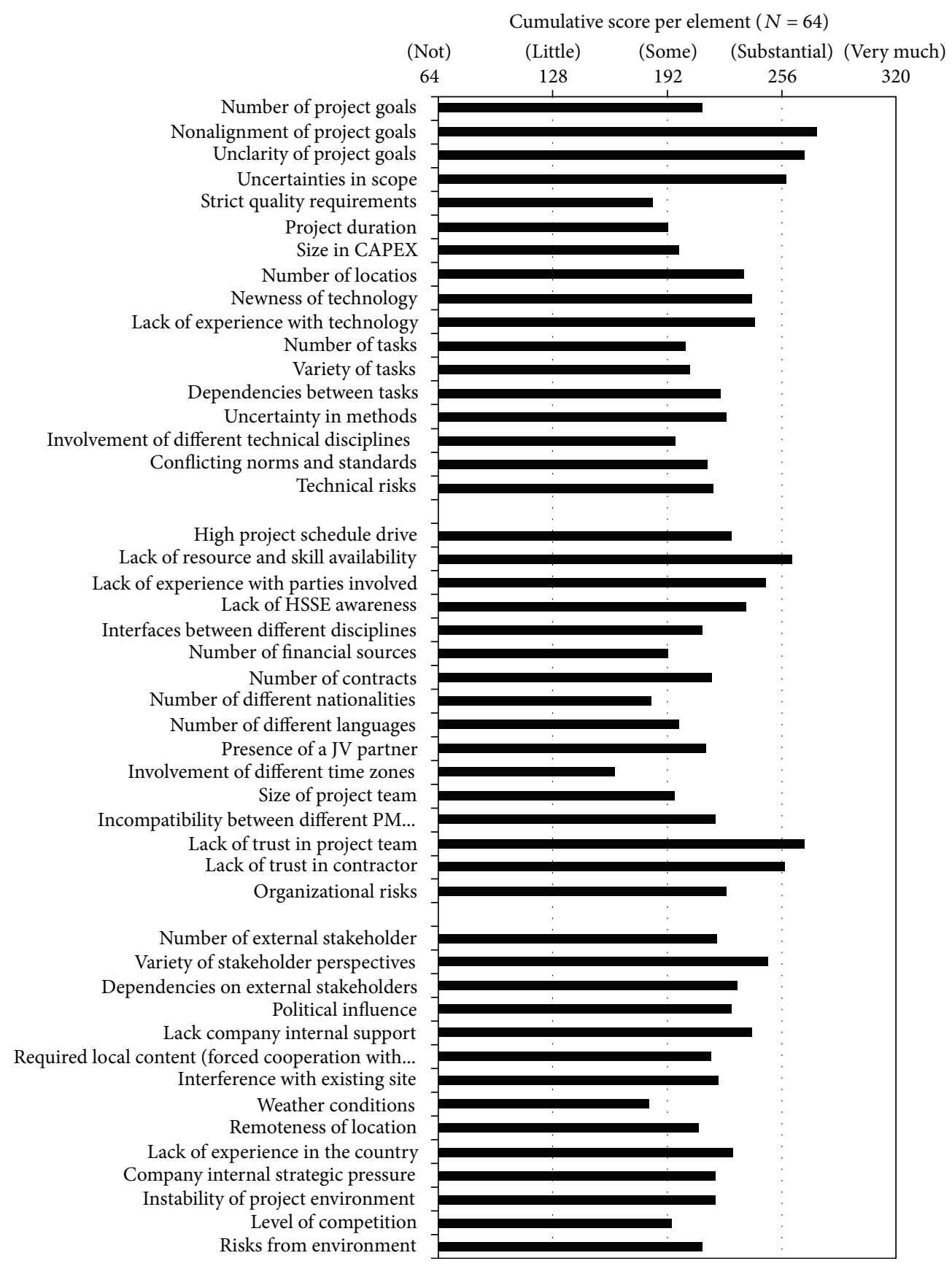

Figure 3: Results sector A ([7], Figure 9.3).

T-elements includes elements related to project goals and project scope and that these elements were mentioned by more than half of the respondents. There seems considerable agreement amongst the respondents about the importance of these elements, which also confirms research in the construction industry [25]. The most often mentioned O-element is a lack of resource and skills availability, mentioned by about $70 \%$ of the respondents. This seems a trivial element contributing to complexity of a project: if resources are lacking, realizing project objectives becomes troublesome. Also, it might highlight a serious problem that occurs in current project practice which has to deal with constrained resources. As literature highlights, improved project portfolio management might be needed to optimally distribute the available resources [26]. The availability of resources and skills is outside the responsibility of the project manager [27]. From the O-complexity elements, also a lack of trust in the project team was mentioned often (by $50 \%$ of the respondents), indicating the importance of obtaining trust in a project team, which also is stressed in literature [28]. For the E-elements, the element variety of stakeholders' perspectives was mentioned most often, by almost $60 \%$ of the respondents. This is the only E-element for which such high agreement was found under the respondents; other elements scored lower than 50\%. 
TABLE 4: Top-3 of most contributing complexity elements-sector A.

\begin{tabular}{lc}
\hline $\begin{array}{l}\text { Most contributing to project } \\
\text { complexity }\end{array}$ & $\begin{array}{c}\text { Percentage of respondents } \\
(N=64)\end{array}$ \\
\hline Technical & $58 \%$ \\
Nonalignment of project goals & $56 \%$ \\
Uncertainties in scope & $55 \%$ \\
Unclarity of project goals & \\
\hline Organizational & $70 \%$ \\
Lack of resource and skills availability & $50 \%$ \\
Lack of trust in project team & $38 \%$ \\
High schedule drive & \\
\hline External & $58 \%$ \\
Variety of stakeholders' perspectives & $44 \%$ \\
Lack of company internal support & $28 \%$ \\
Interference with existing site & $28 \%$ \\
Lack of experience in the country &
\end{tabular}

3.2. Sector B: Construction and Infra. Generally, the respondents in research sector $B$ had less experience in the role they were playing in the project management field. However, the total number of respondents was considerably higher (see Figure 4).

The respondents indicated to what extent the TOE elements (potentially) contributed to their project's complexity. Amongst the highest-scoring elements are no (!) T-elements, one O-element (schedule drive), and several E-elements: stakeholder-related (number external stakeholders, variety in stakeholder's perspectives) or physical environment related (remoteness of environment). Apparently, technology is not posing the major challenges in the projects under consideration. The general average scores tended to "some" contribution to project complexity (and not the higher substantial or very much).

From the elements the respondents rated "substantial" or "very much," they selected their top-3 elements (see Table 5). Note that a considerable number of the respondents did not score project complexity high enough to answer this question (20 for the T-elements, 18 for the O-elements, and 18 for the E-elements).

Amongst the top-3 elements as presented in Table 5, there is only one element that was specifically added to the TOE framework to better capture construction complexities (building logistics and accessibility). Hence, the "original" TOE framework (Figure 1) seems to cover the most contributing complexity elements reasonably well. In other words, aspects most contributing to project complexity seem to have a rather generic character.

We could summarize the results in Table 5 in complexities related to interfaces, complexities related to planning and resourcing, and complexities related to content and stakeholders. Particularly, interfaces appear often in the top-3 elements: in the T-category, the elements dependencies between tasks and involvement of different technical disciplines are mentioned, in the O-category the elements interfaces between different disciplines and building logistics and accessibility are mentioned, and in the E-category the elements interference with existing site/projects and remoteness of location are mentioned. In the O-category, a high schedule drive is mentioned by more than a third of the respondents, which is in combination with a lack of resources and skills availability rather problematic. In the E-category, the influence of external stakeholders seems to cause complexity, given the high scores of variety of external stakeholders' perspectives, political influence, and number of external stakeholders.

3.3. Sector C: ICT. The respondents' experience in project management in research sector $\mathrm{C}$ is given in Figure 5. Although the number of respondents is limited $(N=8)$, they have considerable experience in the field of project management.

The respondents were asked to score the complexity elements, but in contrast to the investigations in sectors $A$ and $\mathrm{B}$, they were not asked to identify their top-3s. Therefore, Table 6 only shows the highest-scoring elements in view of the respondents.

The ICT respondents score the T-elements generally low: apparently, they do not expect particular complexities from the technical area, apart from dependencies between tasks. They do experience complexity as a result of the $\mathrm{O}$ elements high project schedule drive and interfaces between different disciplines. They, however, expect most complexities from E-elements, particularly related to stakeholder involvement, both internal and external to the company.

3.4. Sector D: High-Tech Product Development. The work experience of the respondents in sector D ranged between 7 and 28 years, with an average working experience of 18 years. On top of this relatively long work experience, the majority of the respondents was PMP certified (11 respondents) and two were busy attaining a certification.

Similar to the research in sector C, the respondents were asked to score the complexity elements on a scale from 1 to 5 (not contributing to very much contributing). Results are given in Table 7.

The respondents score the T-elements relatively high in their contribution to project complexity. Amongst the highest-scoring elements, there is only one E-element (level of competition) and one O-element (high project schedule drive) whereas there are five T-elements. These highscoring T-elements seem to reflect the high-tech products that are being created in their major projects (size in CAPEX), requiring the involvement of different technical disciplines, organized with a high number and variety of tasks and involving technical risks. The O-element and the E-element are probably related as well: because of high competition in the business under investigation, the projects are primarily (and strongly) schedule-driven: if you are not the first, you will lose the market.

3.5. Sector E: Food Processing Industry. The work experience of the respondents in the food processing industry ranged from 5 to 34 years with an average of 21 years. The project management experience of the participants was between 2 and 30 years averaging at 13 years (see Figure 6). 


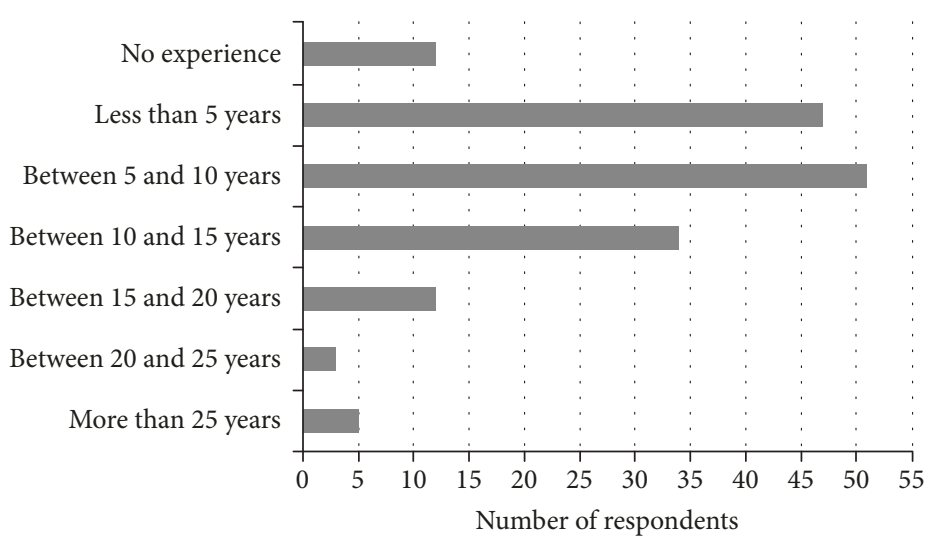

FIGURE 4: Experience of respondents $(N=164)$.

TABLE 5: Top-3 of most contributing complexity elements-sector B.

\begin{tabular}{lc}
\hline Most contributing to project complexity & $\begin{array}{c}\text { Percentage of } \\
\text { respondents }\end{array}$ \\
\hline Technical & $(N=144)$ \\
Dependencies between tasks & $38 \%$ \\
Uncertainties in scope & $28 \%$ \\
Project duration & $26 \%$ \\
Involvement of different technical & $23 \%$ \\
disciplines & $(N=146)$ \\
\hline Organizational & $36 \%$ \\
High project schedule drive & $28 \%$ \\
Interfaces between different disciplines & $23 \%$ \\
Lack of resource and skills availability & $22 \%$ \\
Building logistics and accessibility & $(N=146)$ \\
\hline External & $50 \%$ \\
Remoteness of location & $36 \%$ \\
Variety of external stakeholders' & $23 \%$ \\
perspectives & $23 \%$ \\
Political influence & $21 \%$ \\
Interference with existing site/projects & \\
Number of external stakeholders & \\
\hline
\end{tabular}

Similar to the research in the sectors $\mathrm{C}$ and $\mathrm{D}$, the respondents were asked to score each of the complexity elements on a scale from 1 to 5 (not contributing to very much contributing). The results for the seven (7) highest-ranking elements are presented in Table 8.

The respondents scored the T-elements relatively moderate compared to the $\mathrm{O}$ - and the E-elements where the highest scores were found (all top 5 scores). Amongst the top seven elements, there are only two $\mathrm{T}$ elements, strict quality requirements and project duration. The first of these is clearly sector-specific and related to food safety: the strict food quality requirements that this industry has to deal with. The top two scoring elements are from the organizational category and are similar to those found in other industries: lack of resources and skills availability and high project schedule drive. The third highest-ranking element is from the external category and is also recognizable from the earlier sectors/studies: interference with existing site. The final two elements out of the top seven are closely related company internal strategic pressure and internal stakeholders.

3.6. Comparing the Complexities in the Five Industries. Table 9 presents a summarizing overview of the results of the preceding sections. All high-scoring elements are displayed in the rows of this table; an "X" means that this complexity element belonged to the highest-scoring elements in that specific sector. Given the different character of the datasets (in terms of number and character of the data points gathered), it was not possible to enhance this comparison with more elaborated statistical analysis. However, this comparison does provide insight in high-scoring elements across the five sectors.

For the highest-scoring T-elements as listed in Table 9, only four of the eleven complexity elements were concluded from two industry sectors. These are uncertainties in scope, dependencies between tasks, involvement of different technical disciplines, and project duration. Complexities in the hightech industry seem to be driven more by content-related elements than complexities in the other industries. The ICT sector seems not to bother about technical complexities, according to the current study. In the process industry, the complexity elements related to the project goals are emphasized: unclarity of goals and unalignment of goals are amongst the highest-scoring T-elements. The element project duration seems a complexity element specifically related to the construction industry where projects with a 20-year or 30-year contract period become more and more common and a complexity element related to the food processing industry. The strict quality requirements that were found as a highscoring complexity element in the food processing industry are clearly related to their specific context (food safety). Based on this data, the T-complexities seem rather industry-specific.

More alignment between industries is found for the $\mathrm{O}$ elements, contributing to project complexity. From the six highest-scoring O-elements, three are shared by two or more sectors. In all five researches, the complexity element high project schedule drive is amongst the highest-scoring complexity elements, hence stressing the importance of realistically estimating project schedules. The element lack of 


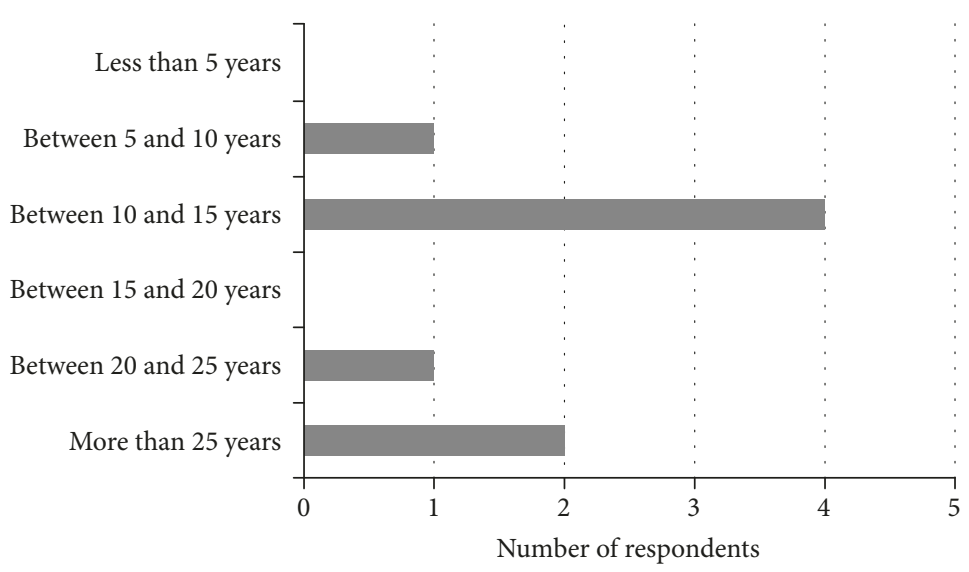

FIGURE 5: Project management experience of respondents $(N=8)$.

TABLE 6: Highest-scoring complexity elements-sector C.

\begin{tabular}{|c|c|c|c|c|c|c|c|c|c|}
\hline Elements contributing to project complexity & SUM & Case 1 & Case 2 & Case 3 & Case 4 & Case 5 & Case 6 & Case 7 & Case 8 \\
\hline \multicolumn{10}{|l|}{ Technical } \\
\hline Dependencies between tasks & 28 & 5 & 4 & 4 & 4 & 3 & 1 & 3 & 4 \\
\hline \multicolumn{10}{|l|}{ Organizational } \\
\hline High project schedule drive & 28 & 5 & 4 & 2 & 5 & 2 & 2 & 4 & 4 \\
\hline Interfaces between different disciplines & 25 & 2 & 4 & 3 & 3 & 1 & 4 & 4 & 4 \\
\hline \multicolumn{10}{|l|}{ External } \\
\hline Variety of external stakeholders' perspectives & 24 & 4 & 4 & 1 & 4 & 4 & 2 & 4 & 1 \\
\hline Dependencies on external stakeholders & 23 & 5 & 4 & 1 & 5 & 2 & 1 & 4 & 1 \\
\hline Political influence & 21 & 4 & 4 & 1 & 5 & 5 & 2 & 0 & 0 \\
\hline Company internal strategic pressure & 25 & 5 & 4 & 1 & 5 & 4 & 3 & 2 & 1 \\
\hline
\end{tabular}

TABLE 7: Highest scoring complexity elements-sector D.

\begin{tabular}{lccc}
\hline $\begin{array}{l}\text { Elements contributing to } \\
\text { project complexity }\end{array}$ & $\begin{array}{c}\text { Average } \\
\text { score }\end{array}$ & $\begin{array}{c}\text { Standard } \\
\text { deviation }\end{array}$ & $N$ \\
\hline $\begin{array}{l}\text { Technical } \\
\text { Involvement of different } \\
\text { technical disciplines }\end{array}$ & 4.06 & 0.68 & 16 \\
$\begin{array}{l}\text { Technical risks } \\
\text { Size in CAPEX }\end{array}$ & 4.00 & 1.15 & 16 \\
$\begin{array}{l}\text { Number of tasks } \\
\text { Variety of tasks }\end{array}$ & 3.56 & 1.26 & 16 \\
\hline $\begin{array}{l}\text { Organizational } \\
\text { High project schedule }\end{array}$ & 3.56 & 1.21 & 16 \\
drive & 4.63 & 0.96 & 16 \\
\hline $\begin{array}{l}\text { External } \\
\text { Level of competition }\end{array}$ & 4.44 & 0.63 & 16 \\
\hline
\end{tabular}

resource and skills availability is concluded from three researches: process, construction, and food processing. Scarcity in resources is a known problem in projects, and it is surprising that it does not appear in all five sectors under consideration. The element interfaces between different disciplines is shared by construction and ICT. The complexity related to interfaces is easily understood for construction and ICT: projects in both sectors have close connections to other sectors and/or rely on these interfaces. To give some examples: the construction of a new station is next to the construction itself closely related to the related infrastructure and future users (exploitation of the station), and the development of a computer program in ICT itself is more an enabler for obtaining a wider goal, often overarching disciplines.

Almost similar to the T-elements (eleven), ten Eelements made it into the list of highest-scoring complexity elements in Table 9, four of which are shared by at least two industries. The element variety of external stakeholders' perspectives is amongst the highest-scoring complexity elements in the process, construction, and ICT industries. Only in the high-tech, new product development industry, which is dominantly internally focused for the development of new products, this complexity element is not scored high. That a high number of parties involved is causing complexities is also visible from some other elements in Table 9: number of external stakeholders involved (construction industry) and dependencies on external stakeholders (ICT industry). A specific party causing complexities seem the politicians: the element political influence appears amongst the highestscoring elements in both construction and ICT. The projects 


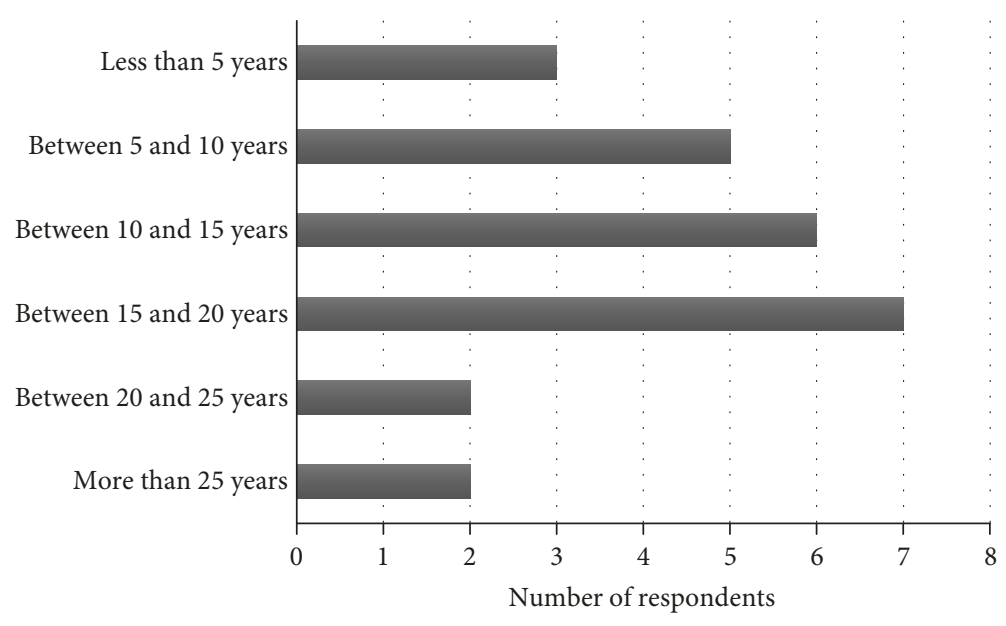

Figure 6: Project management experience of respondents $(N=25)$.

TABLE 8: Highest-scoring complexity elements—sector E.

\begin{tabular}{lccc}
\hline $\begin{array}{l}\text { Elements contributing to } \\
\text { complexity }\end{array}$ & $\begin{array}{c}\text { Average } \\
\text { score }\end{array}$ & $\begin{array}{c}\text { Standard } \\
\text { deviation }\end{array}$ & N \\
\hline $\begin{array}{l}\text { Technical } \\
\text { Project duration }\end{array}$ & 3.40 & 1.15 & 25 \\
Strict quality requirements & 3.48 & 0.87 & 25 \\
\hline $\begin{array}{l}\text { Organizational } \\
\text { High project schedule drive }\end{array}$ & 4.00 & 0.83 & 25 \\
$\begin{array}{l}\text { Lack of resources and skills } \\
\text { availability }\end{array}$ & 4.04 & 0.81 & 25 \\
$\begin{array}{l}\text { Internal stakeholders } \\
\text { External }\end{array}$ & 3.58 & 1.13 & 25 \\
$\begin{array}{l}\text { Interference with existing site } \\
\text { Company internal strategic }\end{array}$ & 3.88 & 0.95 & 25 \\
pressure & 3.60 & 1.03 & 25 \\
\hline
\end{tabular}

under investigation in these sectors both did have a (strong) link with the public parties, in contrast to the high-tech product development projects or the projects in the process industry. The importance of the element interference with the existing site was found in both the construction industry, the process industry, and the food processing industry. In the process industry, this element relates, for example, to the difference between Greenfield or Brownfield projects. A Greenfield project implies that all is to be built from scratch, whereas Brownfield projects have a direct link to existing facilities with ongoing operations (and related complexities). Similarly, in construction there is the difference between constructing a brand new road in a rural area or reconstructing a train station where the train service cannot be interrupted. Complexity caused by strategic issues like a lack of company internal support or company internal strategic pressure was seen in the process industry and the ICT sector, respectively. Only the most innovative sector (high-tech product development) experienced the level of competition as an element contributing to project complexity.

Summarizing the findings as presented in Table 9: (i) A few elements appear in three or more of the five industries: high project schedule drive, lack of resource and skills availability, variety of external stakeholders' perspectives, and interference with existing site. These elements demonstrate their broad applicability and importance in determining project complexity.

(ii) Other elements appear in one sector and seem to have a more sector-specific character: for example, remoteness of location for the construction industry, technical risk for high-end product development, unclarity and unalignment of project goals for the process industry, and strict quality requirements for the food processing industry.

\section{Results: The Value of Using a Complexity Framework}

A necessary condition to create support for implementation of a new complexity framework is its value for the people who work with it. Once potential users see the value of a new tool, it is more likely they will explore it and actually start using it $[29,30]$. In the sector A research (process industry), respondents were specifically asked for their view on the added value of the TOE framework. Results, clustered into overarching themes, are provided in Table 10.

Only four of the respondents did not see any added value. Some others did not know or did not understand the question, but the majority of the respondents did see a clear added value, for example, in the areas of structuring, decisionmaking, and stakeholder alignment and management.

The TOE framework could help in achieving better alignment in the team and better communication with stakeholders. Also, the structured approach of the TOE framework adds value to the project, in view of the respondents. Based on the outcome of a TOE complexity assessment, activities could be selected to manage those complexities that gained the highest priority. One of the actions could be to staff the project accordingly, similar to earlier publications on matching the project manager's competences to the particular project complexity $[31,32]$. 
TABLE 9: Elements of the TOE framework most contributing to complexity.

\begin{tabular}{|c|c|c|c|c|c|}
\hline $\begin{array}{l}\text { Those elements most contributing to } \\
\text { complexity }\end{array}$ & $\begin{array}{c}\text { Sector A } \\
\text { Process } \\
\text { industry }\end{array}$ & $\begin{array}{c}\text { Sector B } \\
\text { Construction } \\
\text { industry }\end{array}$ & $\begin{array}{c}\text { Sector C } \\
\text { ICT } \\
\text { industry }\end{array}$ & $\begin{array}{c}\text { Sector D } \\
\text { High-tech } \\
\text { industry }\end{array}$ & $\begin{array}{c}\text { Sector E } \\
\text { Food } \\
\text { industry }\end{array}$ \\
\hline \multicolumn{6}{|l|}{ T-elements } \\
\hline Uncertainties in scope & $\mathrm{X}$ & $\mathrm{X}$ & & & \\
\hline Dependencies between tasks & & $\mathrm{X}$ & $\mathrm{X}$ & & \\
\hline Involvement of different technical disciplines & & $\mathrm{X}$ & & $\mathrm{X}$ & \\
\hline Unclarity of project goals & $\mathrm{X}$ & & & & \\
\hline Nonalignment of project goals & $\mathrm{X}$ & & & & \\
\hline Project duration & & $\mathrm{X}$ & & & $\mathrm{X}$ \\
\hline Technical risks & & & & $\mathrm{X}$ & \\
\hline Size in CAPEX & & & & $\mathrm{X}$ & \\
\hline Number of tasks & & & & $\mathrm{X}$ & \\
\hline Variety of tasks & & & & $\mathrm{X}$ & \\
\hline Strict quality requirements & & & & & $\mathrm{X}$ \\
\hline \multicolumn{6}{|l|}{ O-elements } \\
\hline High project schedule drive & $\mathrm{X}$ & $\mathrm{X}$ & $\mathrm{X}$ & $\mathrm{X}$ & $\mathrm{X}$ \\
\hline Lack of resource and skills availability & $\mathrm{X}$ & $\mathrm{X}$ & & & $\mathrm{X}$ \\
\hline Interfaces between different disciplines & & $\mathrm{X}$ & $\mathrm{X}$ & & \\
\hline Lack of trust in project team & $\mathrm{X}$ & & & & \\
\hline Building logistics and accessibility & & $\mathrm{X}$ & & & \\
\hline Internal stakeholders & & & & & $\mathrm{X}$ \\
\hline \multicolumn{6}{|l|}{ E-elements } \\
\hline Variety of external stakeholders' perspectives & $\mathrm{X}$ & $\mathrm{X}$ & $\mathrm{X}$ & & \\
\hline Interference with existing site/projects & $\mathrm{X}$ & $\mathrm{X}$ & & & $\mathrm{X}$ \\
\hline Political influence & & $\mathrm{X}$ & $\mathrm{X}$ & & \\
\hline Number of external stakeholders & & $\mathrm{X}$ & & & \\
\hline Remoteness of location & & $\mathrm{X}$ & & & \\
\hline Lack of company internal support & $\mathrm{X}$ & & & & \\
\hline Lack of experience in the country & $\mathrm{X}$ & & & & \\
\hline Dependencies on external stakeholders & & & $\mathrm{X}$ & & \\
\hline Company internal strategic pressure & & & $\mathrm{X}$ & & $\mathrm{X}$ \\
\hline Level of competition & & & & $\mathrm{X}$ & \\
\hline
\end{tabular}

TABLE 10: Added value of the TOE complexity framework, adapted from [7].

\begin{tabular}{lc}
\hline Answers related to: & Sector A responses $(N=64)$ \\
\hline Better alignment & 8 \\
Structured approach & 12 \\
Communication with stakeholders & 4 \\
Support decision-making & 8 \\
Identify priorities & 7 \\
Integrate & 3 \\
Awareness & 3 \\
No added value & 4 \\
Not applicable & 3 \\
Don't know & 12 \\
Question not well understood & 4 \\
\hline
\end{tabular}

\section{Discussion}

In this section, the findings and implications of this research are discussed. Also, the limitations of the current research are described.

5.1. Differences and Similarities: Opportunities for Learning Across Sectors? Projects are unique, and at the same time they are not unique in all their aspects. This research shows there are similarities in complexities across projects in different sectors ((food) process, ICT, high-tech products, and construction industry) in terms of high-scoring complexity elements, but also differences are found. Both imply opportunities for cross-sector learning and show the applicability of the TOE framework in other industries than the process industry for which the framework initially was developed [7]. 
Cross-sector learning does not imply that we are in favor of a one-size-fits-all approach: rather, we propose a fit-forpurpose management approach in which we carefully select the appropriate management tools, techniques, and processes based on the specific characteristics of the project. The complexity of the project could be the characteristic to base the approach upon. Obviously, it is important then to understand the rationale of complexity in projects.

Referring back to project management literature, we distinguish two main streams. The first stream considers complexity as a subjective phenomenon; the second stream considers complexity as a descriptive property of a system [12]. The TOE complexity framework adopts the first stream by emphasizing the subjective nature of complexity and its dynamic character. This dynamism is difficult to grasp objectively, although the complexity theory does describe the behavior of complex systems over time [33]. More important is the question how we can learn in and from projects that are considered complex and how to manage project complexity.

In the infrastructure sector, complex projects seem to ask for a different management approach, characterized by flexibility rather than the more traditional predict and control $[34,35]$. A more flexible project management approach includes the facilitation of collaboration, explorative learning, and adaptation and was shown to positively influence project performance of complex projects [36]. Instead of focusing on reducing project complexity, "playing with complexity" could be considered [6].

This general idea of focusing on embracing complexity rather than reducing complexity could be applied in crosssectoral contexts. And maybe this "embracement" is a lesson to be drawn, given the parallels of the complexity elements that were present in at least three of the sectors considered in this study (high schedule drive, lack of resources and skills availability, variety of stakeholders' perspectives, and interference with existing site). For the element high schedule drive, the idea of complexity reduction seems attractive. High time pressure is a universal phenomenon in nowadays' society, and rather than trying to comply to unrealistic deadlines, better preparation of the project should be allowed for, hence avoiding this high schedule drive. Similarly, it is advisable (and difficult) to avoid a lack of resources and skills availability by timely taking appropriate actions (like realistic resource planning and training of staff). For the element variety of stakeholders' perspectives, active involvement of stakeholders is suggested since broader views might bring surprising insights, hence adding value to the project and improving project performance [37]. Also, the element interference with existing site could benefit from an embracing complexity approach by active involvement of stakeholders, assuming that the interference as such is part of the project anyway.

5.2. Limitations of the Research. This (meta-) research brings together five separate researches all focused on an evaluation of the TOE complexity framework. Ideally, the set-up of the five researches would perfectly replicate each other; however, this was not the case. Still, the comparison is considered meaningful since the highest-scoring complexity elements-overall-were included in each of the five researches. Future research could be more strict in type and amount of data to be gathered in different sectors in order to allow for more enhanced statistical analysis of the comparative data.

The research has a qualitative character; we did not attempt to objectively classify projects in terms of complexity. Although further research could investigate how an objective measure of project complexity would look like, we do not think this is a relevant way to go given the inherent subjective character of complexity.

The data for the current analysis was mainly gathered some years ago, which could be considered as a limitation. Although the current analysis cannot guarantee that no other project complexity elements would be more prominent nowadays, still the research indicates the parallels as discussed earlier, opening up the potential for cross-sectorial learning. Also, based on additional longitudinal research (2012-2015, unpublished), we have indications that the development of complexity "ingredients" is rather stable since then, with an exception for the growing importance of political influence.

Another limitation of this research is found in the fact that only Dutch projects, companies, and organizations are involved, thereby specifically focusing on Dutch project practice. It would be interesting to broaden the research to international contexts, although it is the question to what extent country culture dominates project management culture [38].

\section{Conclusions and Recommendations}

This research investigated perceptions of complexity in large technical projects amongst five industry sectors in the Netherlands. It is concluded that some complexity elements appear relevant in three or more of the industries investigated: high project schedule drive, lack of resources and skills availability, variety of external stakeholders' perspectives, and interference with existing site. These elements demonstrate their broad applicability and importance in determining project complexity. Other complexity elements appear in one sector and seem to have a more sector-specific character: for example, remoteness of location for the construction industry, technical risk for high-end product development, unclarity and unalignment of project goals for the process industry, and strict quality requirements for the food processing industry. Both similarities and differences offer opportunities for (further) cross-sectoral learning, which could be the focus of subsequent research.

It is concluded that applying a framework to grasp project complexity could contribute to creating awareness for the actual (expected) complexities in the project. This awareness could help in improving communication between relevant stakeholders in order to achieve better alignment. Also, the TOE framework provides a structured approach to identifying the complexities in today's projects, without claiming an objective view on complexity.

Further research is foreseen in the area of measuring the subjectivity of complexity and in the area of cross-sectoral learning. Why can the process industry implement successfully all types of ICT systems in their plants while tunnel 
technical installations in large infrastructure projects still are challenging, to say the least?

\section{Disclosure}

A previous version of this paper was orally presented at the ÖTMC Conference 2017 (Porec, Croatia).

\section{Conflicts of Interest}

The authors declare that they have no conflicts of interest.

\section{Acknowledgments}

The authors acknowledge the participants of the separate researches on which this meta-analysis is based. The authors thank the conference attendees for their valuable feedback.

\section{References}

[1] M. Bosch-Rekveldt, Y. Jongkind, H. Mooi, H. Bakker, and A. Verbraeck, "Grasping project complexity in large engineering projects: the TOE (technical, organizational and environmental) framework," International Journal of Project Management, vol. 29, no. 6, pp. 728-739, 2011.

[2] J. G. Geraldi, "What complexity assessments can tell us about projects: dialogue between conception and perception," Technology Analysis and Strategic Management, vol. 21, no. 5, pp. 665-678, 2009.

[3] H. Maylor, R. Vidgen, and S. Carver, "Managerial complexity in project based operations: a grounded model and its implications for practice," Project Management Journal, vol. 39, no. S1, pp. S15-S26, 2008.

[4] L.-A. Vidal and F. Marle, "Understanding project complexity: implications on project management," Kybernetes, vol. 37, no. 8, pp. 1094-1110, 2008.

[5] M. J. C. M. Hertogh, S. K. Baker, P. L. Staal, and E. Westerveld, Managing Large Infrastructure Projects: Netlipse, AT Osborne BV, 2008.

[6] M. Hertogh and E. Westerveld, Playing with Complexity, [Ph.D. Thesis], Erasmus Universiteit Rotterdam, Rotterdam, Netherlands, 2010.

[7] M. G. C. Bosch-Rekveldt, Managing Project Complexity. A Study into Adapting Early Project Phases to Improve Project Performance in Large Engineering Projects, [Ph.D. Thesis], Delft University of Technology, Delft, Netherlands, 2011.

[8] M. Engwall, "No project is an island: linking projects to history and context," Research Policy, vol. 32, no. 5, pp. 789-808, 2003.

[9] D. Howell, C. Windahl, and R. Seidel, "A project contingency framework based on uncertainty and its consequences," International Journal of Project Management, vol. 28, no. 3, pp. 256-264, 2010.

[10] A. J. Shenhar, "One size does not fit all projects: exploring classical contingency domains," Management Science, vol. 47, no. 3, pp. 394-414, 2001.

[11] T. Cooke-Davies, S. Cicmil, L. Crawford, and K. Richardson, "We're not in Kansas anymore, Toto: mapping the strange landscape of complexity theory, and its relationship to project management," Project Management Journal, vol. 38, no. 2, pp. 50-61, 2007.
[12] F. Marle and L.-A. Vidal, Managing Complex, High Risk Projects, Springer, London, UK, 2016.

[13] K. E. Emam and A. G. Koru, "A replicated survey of IT software project failures," IEEE Software, vol. 25, no. 5, pp. 84-90, 2008.

[14] M. G. Mc Kenna, H. Wilczynski, and D. van der Schee, "Capital project execution in the oil and gas industry," 2006, https://www.boozallen.com/media/file/Capital_Project_ Execution.pdf.

[15] J. Söderlund, "Pluralism in project management: navigating the crossroads of specialization and fragmentation," International Journal of Management Reviews, vol. 13, no. 2, pp. 153-176, 2011.

[16] M. G. C. Bosch-Rekveldt, "Applying mixed methods for researching project management in engineering projects," in Designs, Methods and Practices for Research of Project Management, pp. 315-325, Gower Publishing, 2015.

[17] A. Tashakkori and C. Teddlie, Mixed Methodology: Combining Qualitative and Quantitative Approaches, vol. 46, Sage Publications, London, UK, 1998.

[18] W. L. Wallace, The Logic of Science in Sociology, Aldine De Gruyter, 1971.

[19] D. B. Baarda and M. P. M. de Goede, Basisboek Methoden en Technieken, Wolters-Noordhoff, Groningen, Netherlands, 2006.

[20] P. Verschuren and H. Doorewaard, Designing a Research Project, Lemma, Utrecht, Netherlands, 1999.

[21] N. Blaikie, Designing Social Research, Polity Press, Cambridge, UK, 2nd edition, 2009.

[22] J. Helvoort, Complexity in IT projects, [M.S. Thesis], Delft University of Technology, Delft, Netherlands, 2011.

[23] S. Nauta, Investigating Project Complexity in High-Tech Projects, [M.S. Thesis], Delft University of Technology, Delft, Netherlands, 2011.

[24] S. Nauta, M. Bosch-Rekveldt, and H. G. Mooi, "Project complexity in the semiconductor industry: a case study approach," in Paper presented at PMI ${ }^{\circledR}$ Research and Education Conference, Limerick, Munster, Ireland, Project Management Institute, Newtown Square, PA, USA, 2012.

[25] S. M. H. M. Al-Tmeemy, H. Abdul-Rahman, and Z. Harun, "Future criteria for success of building projects in Malaysia," International Journal of Project Management, vol. 29, no. 3, pp. 337-348, 2011.

[26] Z. Laslo, "Project portfolio management: an integrated method for resource planning and scheduling to minimize planning/ scheduling-dependent expenses," International Journal of Project Management, vol. 28, no. 6, pp. 609-618, 2010.

[27] A. Murray, Managing Successful Projects with PRINCE2 (Office of Government Commerce), The Stationery Office, Norwich, UK, 5th edition, 2009.

[28] J. K. Pinto, D. P. Slevin, and B. English, "Trust in projects: an empirical assessment of owner/contractor relationships," International Journal of Project Management, vol. 27, no. 6, pp. 638-648, 2009.

[29] R. O. Briggs, A. J. Davis, J. D. Murphy, L. Steinhauser, and T. F. Carlisle, "Transferring a collaborative work practice to practitioners: a field study of the value frequency model for change-of-practice," in Groupware: Design, Implementation, and Use, vol. 4715 of Lecture Notes in Computer Science, Springer, Berlin, Heidelberg, 2007. 
[30] R. O. Briggs, J. D. Murphy, T. F. Carlisle, and A. J. Davis, "Predicting change: a study of the value frequency model for change of practice," in 2009 42nd Hawaii International Conference on System Sciences, pp. 1-10, Big Island, HI, USA, 2009.

[31] M. G. C. Bosch-Rekveldt, H. G. Mooi, A. Verbraeck, E. Sjoer, B. Wolsing, and C. Gulden, "Mapping project manager's competences to project complexity," in IPMA 23rd WorldCongress, Research Track Human Side of Projects in Modern Business, pp. 85-96, Helsinki, Finland, 2009.

[32] J. Thomas and T. Mengel, "Preparing project managers to deal with complexity - advanced project management education," International Journal of Project Management, vol. 26, no. 3, pp. 304-315, 2008.

[33] B. Xia and A. P. C. Chan, "Measuring complexity for building projects: a Delphi study," Engineering, Construction and Architectural Management, vol. 19, no. 1, pp. 7-24, 2012.

[34] M. Giezen, "Keeping it simple? A case study into the advantages and disadvantages of reducing complexity in mega project planning," International Journal of Project Management, vol. 30, no. 7, pp. 781-790, 2012.

[35] J. Koppenjan, W. Veeneman, H. Van der Voort, E. Ten Heuvelhof, and M. Leijten, "Competing management approaches in large engineering projects: the Dutch RandstadRail project," International Journal of Project Management, vol. 29, no. 6, pp. 740-750, 2011.

[36] P. E. Eriksson, J. Larsson, and O. Pesämaa, "Managing complex projects in the infrastructure sector - a structural equation model for flexibility-focused project management," International Journal of Project Management, vol. 35, no. 8, pp. 1512-1523, 2017.

[37] F. Di Maddaloni and K. Davis, "The influence of local community stakeholders in megaprojects: rethinking their inclusiveness to improve project performance," International Journal of Project Management, vol. 35, no. 8, pp. 1537-1556, 2017.

[38] L. Koops, M. Bosch-Rekveldt, H. Bakker, and M. Hertogh, "Exploring the influence of external actors on the cooperation in public-private project organizations for constructing infrastructure," International Journal of Project Management, vol. 35, no. 4, pp. 618-632, 2017. 


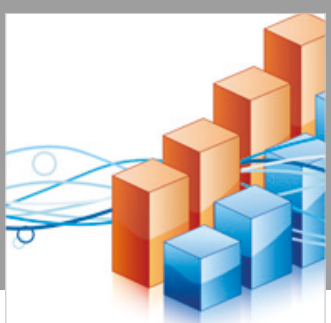

Advances in

Operations Research

\section{-n-m}
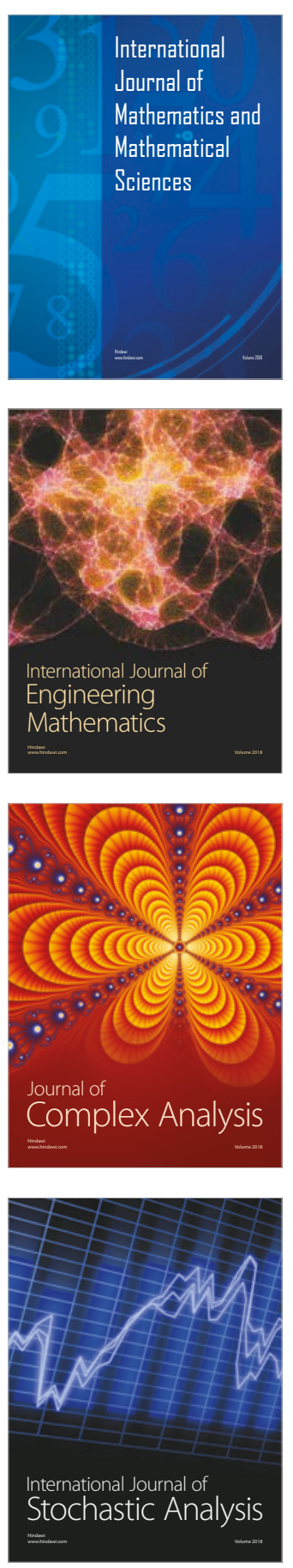
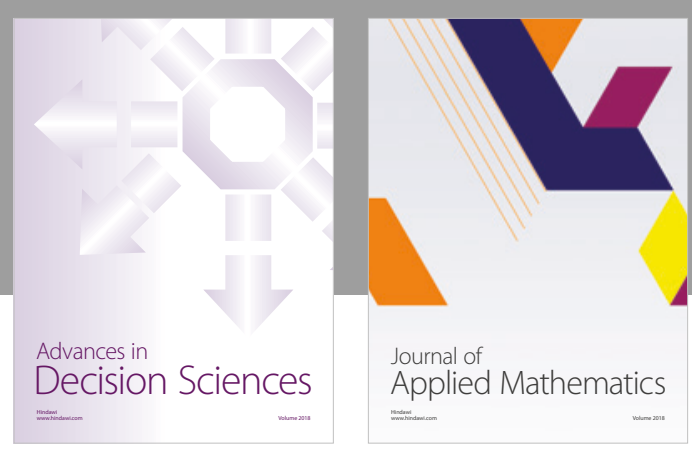

Journal of

Applied Mathematics
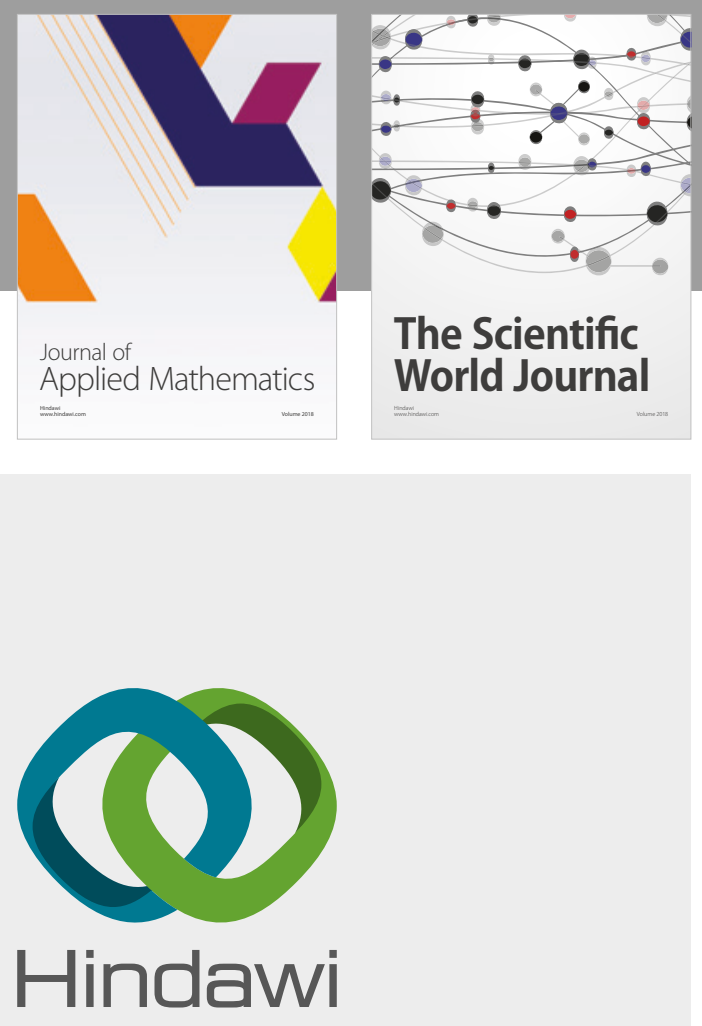

Submit your manuscripts at

www.hindawi.com

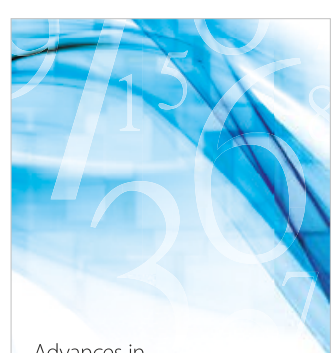

Advances in
Numerical Analysis
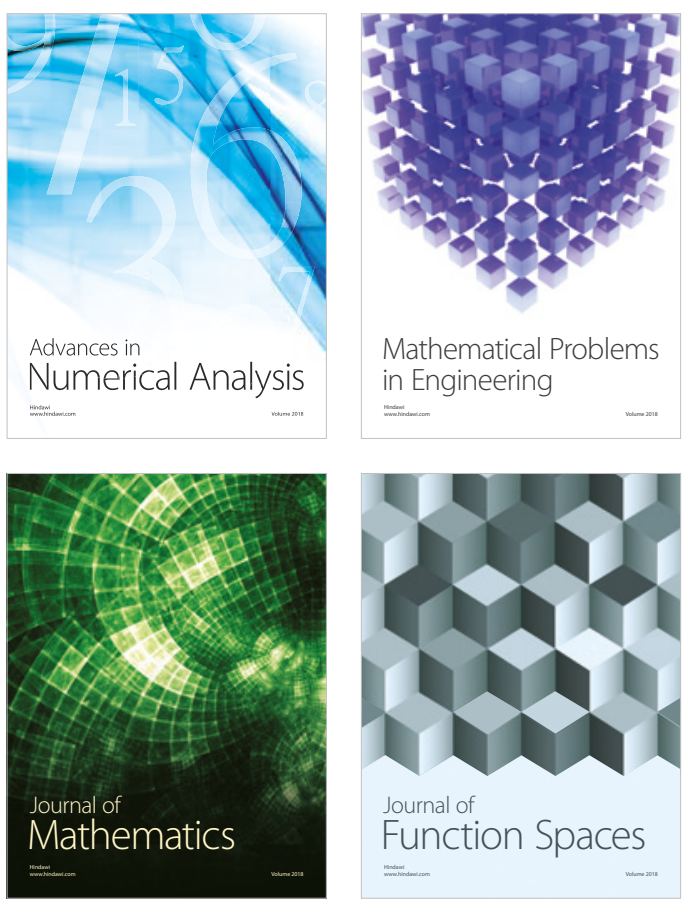

Mathematical Problems in Engineering

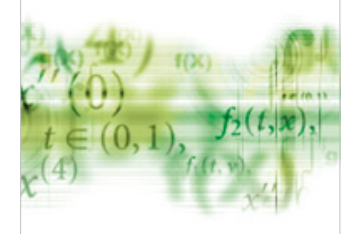

International Journal of

Differential Equations

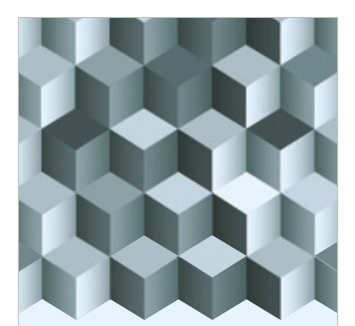

Journal of

Function Spaces
The Scientific

World Journal

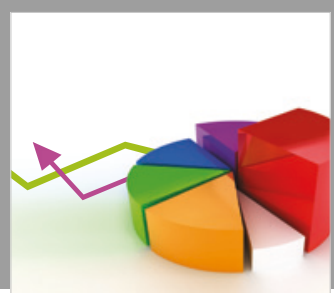

Journal of

Probability and Statistics
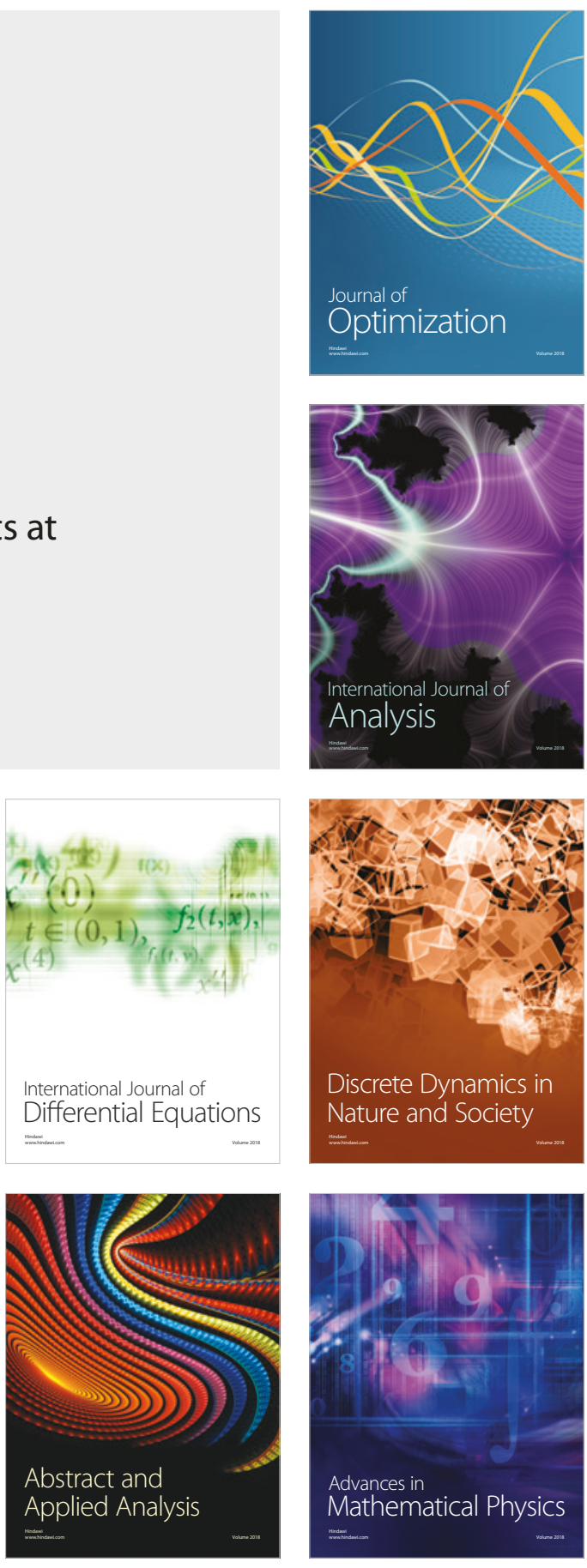